\title{
Optimal waste loading in high-level nuclear waste glass from high-burnup spent fuel for waste volume and geological disposal footprint reduction
}

\author{
Tomofumi Sakuragi ${ }^{1}$ (1) $\cdot$ Tomohiro Okamura $^{2} \cdot$ Ryo Hamada $^{1} \cdot$ Hidekazu Asano $^{1,2} \cdot$ Eriko Minari $^{2} \cdot$ Masahiko Nakase $^{2}$. \\ Kenji Takeshita ${ }^{2} \cdot$ Toshiro Oniki $^{3} \cdot$ Midori Uchiyama $^{3}$
}

Received: 28 November 2021 / Accepted: 4 February 2022 / Published online: 11 February 2022

(c) The Author(s) 2022

\begin{abstract}
The effects of waste loading in vitrified high-level nuclear waste (HLW) from the reprocessing of high-burnup spent fuel (56 $\mathrm{GWd} / \mathrm{tHM}$ ) on waste volume reduction (i.e., number of HLW canisters produced) and decay heat generation were investigated to minimize the repository footprint. As the waste loading increases, the number of canisters produced decreases; however, the decay heat and subsequent footprint per canister increase. The best estimate waste loading observed was $23 \mathrm{wt} \%$ (including $10 \mathrm{wt} \% \mathrm{Na}_{2} \mathrm{O}$ ), wherein the repository footprint minimizes to $60.0 \mathrm{~m}^{2} / \mathrm{tHM}$. These results are slightly higher than those for standard HLW $\left(55.5 \mathrm{~m}^{2} / \mathrm{tHM}\right)$. However, upon comparing the repository footprint with electric power generation, the benefit of optimization was that the footprint for high-burnup HLW $\left(131 \mathrm{~m}^{2} / \mathrm{TWh}\right)$ was $13 \%$ smaller than that of standard HLW $\left(151 \mathrm{~m}^{2} / \mathrm{TWh}\right)$.
\end{abstract}

\section{Introduction}

In view of the safe geological disposal of high-level waste (HLW) in Japan, the properties of standard vitrified HLW in canisters are evaluated assuming a spent fuel burnup of 45 GWd/tHM (Giga Watt-days per metric ton of heavy metal), a spent fuel cooling time of 4 years, and a waste loading of $20.8 \mathrm{wt} \%$ (including $\mathrm{Na}_{2} \mathrm{O}$ ) $[1,2]$. However, considering current consumption trends, where nuclear fuel burnup continues to increase owing to the economical operation of nuclear power plants, the rise in nuclear waste inventory, decay heat, and subsequent waste volume (the number of vitrified HLW canisters produced) poses a challenge with regard to its reprocessing, interim storage, and final disposal.

By increasing the waste loading in the vitrified HLW, the waste volume can be reduced, but the decay heat generation

Tomofumi Sakuragi

sakuragi@rwmc.or.jp

1 Radioactive Waste Management Funding and Research Center, Akashicho 6-4, Chuo city, Tokyo 104-0044, Japan

2 Tokyo Institute of Technology, Ookayama 2-12-1, Meguro city, Tokyo 152-8550, Japan

3 IHI Corporation, Shinnakahara-cho 1, Isogo-ku, Yokohama city 235-8501, Japan of the vitrified HLW canister will increase along with an increase in molybdenum and platinum group metals, which negatively affects vitrification [3]. The increase in decay heat generation affects the thermal constraint of the repository, where the temperature of the bentonite buffer surrounding the waste form is limited to below $100{ }^{\circ} \mathrm{C}$; otherwise, the repository footprint would be greater than expected.

Accordingly, this study investigated the effects of waste loading on the waste volume and heat generation in the vitrified HLW from the reprocessing of high-burnup spent fuel and optimized the waste loading to minimize the repository footprint under the thermal constraint of the repository. We also focused on the spent fuel cooling time (interim storage period) because it is an important factor affecting the decay heat of HLW due to the build-up of ${ }^{241} \mathrm{Am}$ from ${ }^{241} \mathrm{Pu}$ decay in spent fuel.

\section{Methodology}

The radionuclide inventory and decay heat of the vitrified HLW in the canisters were calculated using the general isotope calculation code ORIGEN2.2-UPJ [4] with the crosssection library JENDL4.0/ORLIBJ40 [5]. Based on the recent fuel developments, the spent fuel burnup is assumed to be $56 \mathrm{GWd} / \mathrm{tHM}$. The spent fuel cooling time implies 
the interim storage period before reprocessing. Recently, the shortest cooling time in the new reprocessing standard in Japan was changed from 4 to 15 years [6]. Thus, this study assumed a cooling time of $15-40$ years. Detailed calculation conditions for the vitrified HLW are given in the Supplementary information (Table S1).

COMSOL Multiphysics ${ }^{\circledR}$ v. 5.6 was used for the thermal analysis of the geological repository system, to study the heat released by the vitrified HLW. The engineered barrier design, near-field system, and repository environment are based on the reference case in the Japanese safety case [1] as follows: hard rock (crystalline), 1000-m-deep underground, initial surrounding temperature of $45^{\circ} \mathrm{C}$, and vertical HLW emplacement. The boundary conditions for the heat transfer were $15{ }^{\circ} \mathrm{C}$ at the ground surface, $51^{\circ} \mathrm{C}$ at the bottom $(1200 \mathrm{~m})$ with a temperature gradient of $3{ }^{\circ} \mathrm{C} / 100 \mathrm{~m}$, and adiabatic on all sides. Owing to the mechanical stability of the host rock, the minimum distance between the tunnels is $10 \mathrm{~m}$, which is assumed to be constant in the present work. The canister pitch (distance between the vitrified HLW for vertical emplacement) is $4.44 \mathrm{~m}$ or higher. By increasing the pitch, the canister's footprint (area around one HLW canister) can be increased to $44.4 \mathrm{~m}^{2} /$ canister or larger.

\section{Results and discussion}

Table 1 shows the effects of waste loading and spent fuel cooling time for vitrified HLW in the canisters on waste volume reduction (i.e., the number of canisters produced) and the glass components for a high-burnup HLW of 56 $\mathrm{GWd} / \mathrm{tHM}$ compared with the standard HLW, which is denoted by an asterisk (45 GWd/tHM and a 4-year cooling time) [1]. As the waste loading increases, the number of canisters produced (per tons HM) can be decreased to less than 1.25 canisters/tHM for the standard HLW (20.8 wt $\%$ waste loading). The cooling time has a negligible effect on the number of canisters produced, as well as Mo and Pt group metals (PGM: Ru, Rh, and Pd). As the waste loading increases, the initial heat generation also increases but is lower than the required heat limit of $2.3 \mathrm{~kW} /$ canister because of the longer cooling time of 15 years or more (i.e., decay of fission products). This is also accompanied by a higher enrichment of molybdenum oxide and PGM as compared to the standard HLW. Inagaki et al. [3] suggested that the $\mathrm{MoO}_{3}$ and PGM contents in glass are less than $1.50 \mathrm{wt} \%$ and $1.25 \mathrm{wt} \%$, respectively. Because the
Table 1 Properties of the vitrified HLW from $56 \mathrm{GWd}$ / tHM spent fuel as functions of waste loading and cooling time

\begin{tabular}{|c|c|c|c|c|c|}
\hline \multirow[t]{2}{*}{ Property } & \multirow[t]{2}{*}{ Cooling time (years) } & \multicolumn{4}{|c|}{ Waste loading (wt\%) } \\
\hline & & 20 & 20.8 & 25 & 30 \\
\hline \multirow{6}{*}{$\begin{array}{l}\text { Number of canisters produced } \\
\text { (canisters/tHM) }\end{array}$} & $4(45 \mathrm{GWd} / \mathrm{tHM})$ & 1.35 & $1.25 *$ & 0.897 & 0.673 \\
\hline & 4 & 1.64 & 1.52 & 1.10 & 0.822 \\
\hline & 15 & 1.68 & 1.55 & 1.12 & 0.838 \\
\hline & 20 & 1.68 & 1.56 & 1.12 & 0.841 \\
\hline & 30 & 1.69 & 1.57 & 1.13 & 0.845 \\
\hline & 40 & 1.70 & 1.57 & 1.13 & 0.848 \\
\hline \multirow{6}{*}{$\begin{array}{l}\text { Initial heat generation } \\
\text { (kW/canister) }\end{array}$} & $4(45 \mathrm{GWd} / \mathrm{tHM})$ & 2.16 & $2.34 *$ & 3.25 & 4.33 \\
\hline & 4 & 2.28 & 2.46 & 3.41 & 4.55 \\
\hline & 15 & 0.902 & 0.974 & 1.35 & 1.80 \\
\hline & 20 & 0.796 & 0.860 & 1.19 & 1.59 \\
\hline & 30 & 0.644 & 0.695 & 0.965 & 1.29 \\
\hline & 40 & 0.529 & 0.571 & 0.793 & 1.06 \\
\hline \multirow{6}{*}{$\begin{array}{l}\mathrm{MoO}_{3} \text { content } \\
(\mathrm{wt} \%)\end{array}$} & $4(45 \mathrm{GWd} / \mathrm{tHM})$ & 1.28 & $1.38^{*}$ & 1.29 & 2.56 \\
\hline & 4 & 1.30 & 1.40 & 1.94 & 2.59 \\
\hline & 15 & 1.27 & 1.37 & 1.90 & 2.54 \\
\hline & 20 & 1.26 & 1.37 & 1.90 & 2.53 \\
\hline & 30 & 1.26 & 1.36 & 1.89 & 2.52 \\
\hline & 40 & 1.25 & 1.35 & 1.88 & 2.51 \\
\hline \multirow{6}{*}{$\begin{array}{l}\text { PGM content } \\
(\mathrm{wt} \%)\end{array}$} & $4(45 \mathrm{GWd} / \mathrm{tHM})$ & 1.00 & $1.08^{*}$ & 1.50 & 2.01 \\
\hline & 4 & 1.08 & 1.17 & 1.62 & 2.16 \\
\hline & 15 & 1.06 & 1.14 & 1.59 & 2.11 \\
\hline & 20 & 1.05 & 1.14 & 1.58 & 2.11 \\
\hline & 30 & 1.05 & 1.13 & 1.57 & 2.10 \\
\hline & 40 & 1.05 & 1.13 & 1.57 & 2.09 \\
\hline
\end{tabular}

*Standard HLW (45 GWd/tHM) [1] 
increase in Mo and PGM is a technical challenge to be overcome in the future, this study did not consider the Mo and PGM contents in the vitrified HLW.

Figure 1a shows the post-disposal heat generation for the56-GWd/tHM vitrified HLW and a 25 wt\% waste loading (including $10 \mathrm{wt} \%$ sodium oxide) that had been cooled for 50 years after vitrification. The dashed line at $0.35 \mathrm{~kW} /$ canister is the reference level for the standard HLW at the time of disposal [1]. As mentioned previously, long-term cooling, such as 40 years, decreases the decay heat at the beginning. However, the long-term heat generation after approximately 50 years of disposal slightly increases with the 40-year cooled vitrified waste of before reprocessing as compared to the short-term cooled waste. This is because of the ${ }^{241} \mathrm{Am}$ build-up from ${ }^{241} \mathrm{Pu}$ during the interim storage cooling time.

The thermal effect of the ${ }^{241} \mathrm{Am}$ build-up in the vitrified HLW on the thermal constraint of the bentonite buffer in the repository is clearly demonstrated in Fig. 1b, where the canister's footprint is a minimum of $44.4 \mathrm{~m}^{2} /$ canister. The temperature of the bentonite buffer at the hottest part of the bentonite was over the $100-{ }^{\circ} \mathrm{C}$ limit in all cases. In the shortterm cooling of 15 years, the temperature quickly decreased below $100^{\circ} \mathrm{C}$ within 100 years. However, for the long-term cooling of 40 years, the bentonite buffer will be kept above $100{ }^{\circ} \mathrm{C}$ for nearly 900 years, leading to a large impact on the bentonite degradation to illite.

To lower the temperature of the bentonite buffer, the canister's footprint was increased beyond $44.4 \mathrm{~m}^{2} /$ canister by increasing the canister pitch. According to the thermal analysis (see Supplementary information, Fig. S1), as the canister's footprint increased, the maximum temperature of the bentonite buffer in each footprint decreased. The canister's footprint, adjusted to just below $100{ }^{\circ} \mathrm{C}$, can be obtained for the vitrified HLW with various waste loadings by tuning the pitch in detail. In the case of $25 \mathrm{wt} \%$ waste loading ( $56 \mathrm{GWd} / \mathrm{tHM}$ ), the canister's footprint just below $100{ }^{\circ} \mathrm{C}$ for a cooling time of $15,20,30$, and 40 years are
$67,63,56$, and $54 \mathrm{~m}^{2} /$ canister, respectively (see Supplementary information, Table S2).

Although the canister's footprint increases for higher burnup and waste loading, the waste volume (i.e., number of canisters produced) is reduced with waste loading, as shown in Table 1. Therefore, the total repository footprint can be obtained as follows:

$A=a \times n$,

where $A$ is the repository footprint $\left(\mathrm{m}^{2} / \mathrm{tHM}\right), a$ is the canister's footprint ( $\mathrm{m}^{2} /$ canister), and $n$ is the number of canisters (canisters/tHM). Note that the canister's footprint is adjusted such that the minimum value is $44.4 \mathrm{~m}^{2} /$ canister and the maximum temperature of the bentonite buffer will be just below $100^{\circ} \mathrm{C}$.

Figure $2 \mathrm{a}, \mathrm{b}$ shows the repository footprint of the vitrified HLW for a burnup of 45 and $56 \mathrm{GWd} / \mathrm{tHM}$ with that of the standard HLW in the safety case (reference case) [1]. Regardless of the burnup, the repository footprint decreases with waste loading and then increases. The higher the waste loading, the greater the effect of cooling time. The best estimated waste loading is $23 \mathrm{wt} \%$, where the repository footprint for 40 -year cooled waste is a minimum of 49.1 and $60.0 \mathrm{~m}^{2} / \mathrm{tHM}$ for a burnup of 45 and 56 $\mathrm{GWd} / \mathrm{tHM}$, respectively. The canister's footprint in both cases is $46.0 \mathrm{~m}^{2} /$ canister, and the number of canisters produced is 1.07 and 1.30 canisters/tHM, respectively (see Supplementary information, Tables S2, S3, S5).

Despite optimizing the waste loading, a minimum footprint of $60.0 \mathrm{~m}^{2} / \mathrm{tHM}$ for a high burnup is still larger than that for the standard HLW $\left(55.5 \mathrm{~m}^{2} / \mathrm{tHM}\right)$ [1]. Additionally, the benefit of a higher burnup, that is, electricity generation, was studied. Assuming a thermal efficiency of $34 \%$ for nuclear power generation, the quantity per tHM can be converted into per electricity generation (watthour). The repository footprint per tera watt-hour (TWh) is shown in Fig. 2c, d, and the results are summarized in
Fig. 1 Effect of spent fuel cooling time on the time evolution of $\mathbf{a}$ heat generation rate and $\mathbf{b}$ temperature in bentonite buffer after disposal for the vitrified HLW [56 GWd/tHM and 25 $\mathrm{wt} \%$ waste loading (including $10 \mathrm{wt} \%$ of $\left.\mathrm{Na}_{2} \mathrm{O}\right)$ ]
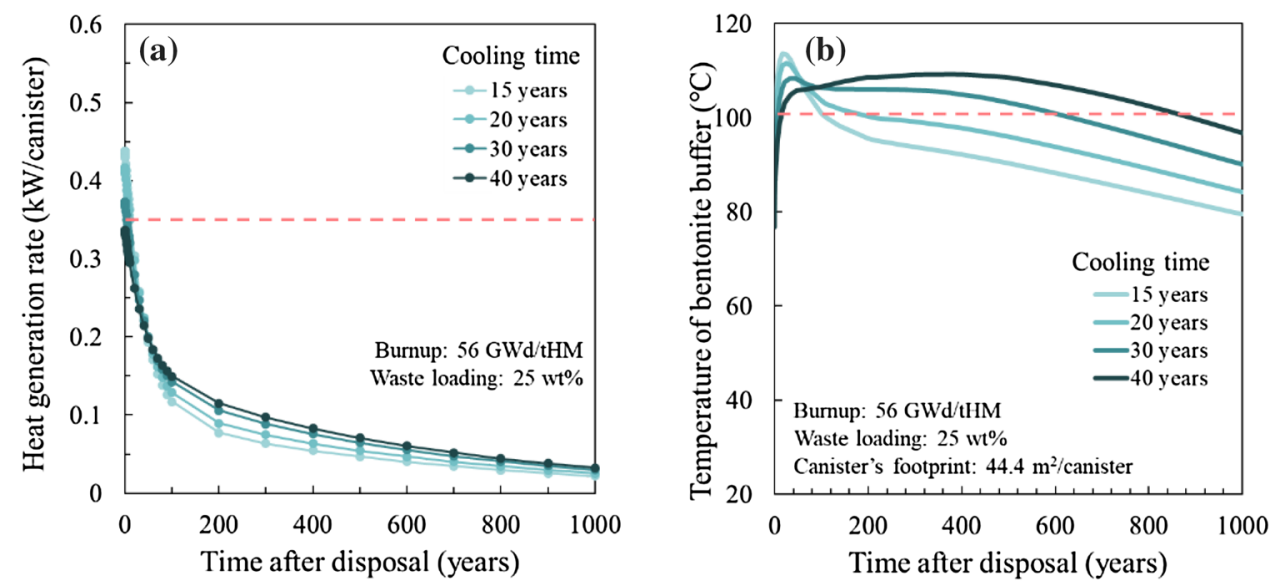
Fig. 2 Repository footprint of the vitrified HLW as a function of waste loading for different cooling times. a, b Footprint per tons of heavy metal (tHM), c, $\mathbf{d}$ footprint per electricity generation (tera watt-hour, TWh). a, c $45 \mathrm{GWd} / \mathrm{tHM}, \mathbf{b}, \mathbf{d} 56 \mathrm{GWd} /$ tHM
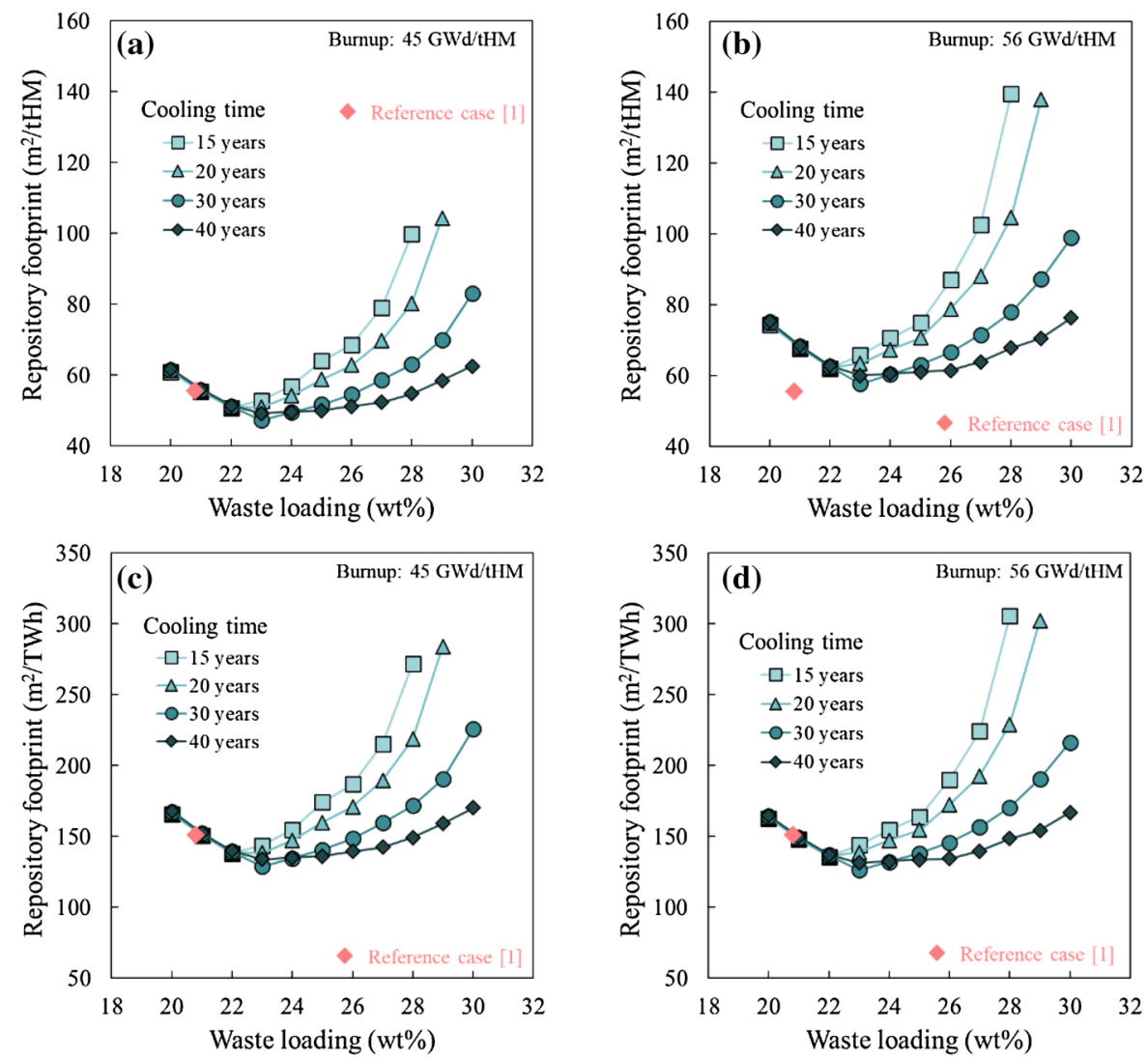

Table 2 Summary of the minimum footprint and optimized waste loading

\begin{tabular}{llll}
\hline & $\begin{array}{l}\text { Standard } \\
\text { HLW [1] }\end{array}$ & \multicolumn{2}{l}{ Present study } \\
\hline Burnup (GWd/tHM) & 45 & 45 & 56 \\
Cooling time (years) & 4 & 40 & 40 \\
Waste loading (wt\%) & 20.8 & 23 & 23 \\
Number of canisters produced & 1.25 & 1.07 & 1.30 \\
$\quad($ canisters/tHM) & & & \\
(canisters/TWh) & 3.40 & 2.91 & 2.85 \\
Repository footprint $\left(\mathrm{m}^{2} / \mathrm{tHM}\right)$ & 55.5 & 49.1 & 60.0 \\
$\left(\mathrm{~m}^{2} / \mathrm{TWh}\right)$ & 151 & 134 & 131 \\
\hline
\end{tabular}

Table 2 (all data are available in the Supplementary information, Tables S2-S6). The best estimated waste loading was $23 \mathrm{wt} \%$. The number of canisters produced was reduced by $16 \%$ from 3.40 canisters/TWh for the standard HLW to 2.85 canisters/TWh. The minimum footprint for a burnup of $56 \mathrm{GWd} / \mathrm{tHM}$ was found to be $131 \mathrm{~m}^{2} / \mathrm{TWh}$, which was $13 \%$ smaller than that for the standard HLW (151 $\left.\mathrm{m}^{2} / \mathrm{TWh}\right)[1]$.

\section{Conclusions}

The waste loading for high-burnup vitrified HLW was optimized under the thermal constraint of the repository to reduce the waste volume and minimize the repository footprint. By appreciating electricity generation as a benefit of higher burnup, the best estimated waste loading was found to be $23 \mathrm{wt} \%$ (including $10 \mathrm{wt} \% \mathrm{Na}_{2} \mathrm{O}$ ), where the number of canisters produced and the repository footprint can be reduced by $16 \%$ and $13 \%$, respectively, compared to those for the standard HLW in the safety case in Japan. The increase in Mo and PGM due to the higher waste loadings poses future technical challenges for waste management strategies to reduce waste volume. There are still various conditions and uncertainties in the nuclear fuel cycle, especially for the geological environment and repository design. Further investigations are required for a better understanding of cross-cutting issues in the nuclear fuel cycle and further optimization.

Supplementary Information The online version contains supplementary material available at https://doi.org/10.1557/s43580-022-00232-3. 
Acknowledgments This work was carried out as a part of the basic research programs of vitrification technology for waste volume reduction supported (JPJ010599) by the Ministry of Economy, Trade and Industry, Japan.

Open Access This article is licensed under a Creative Commons Attribution 4.0 International License, which permits use, sharing, adaptation, distribution and reproduction in any medium or format, as long as you give appropriate credit to the original author(s) and the source, provide a link to the Creative Commons licence, and indicate if changes were made. The images or other third party material in this article are included in the article's Creative Commons licence, unless indicated otherwise in a credit line to the material. If material is not included in the article's Creative Commons licence and your intended use is not permitted by statutory regulation or exceeds the permitted use, you will need to obtain permission directly from the copyright holder. To view a copy of this licence, visit http://creativecommons.org/licenses/by/4.0/.

\section{References}

1. Japan Nuclear Cycle Development Institute (JNC), Second progress report on Research and Development for the geological disposal of HLW in Japan (2000)
2. The nuclear waste management organization of Japan (NUMO), NUMO safety case, NUMO-TR-20-03 (2021) (in Japanese)

3. Y. Inagaki, T. Iwasaki, S. Sato, T. Ohe, K. Kato, S. Torikai, Y. Niibori, S. Nagasaki, K. Kitayama, J. Nucl. Sci. Technol. 46, 677 (2009)

4. http://www.oecd-nea.org/tools/abstract/detail/nea-1642

5. K. Okumura, K. Sugino, K. Kojima et al., A Set of ORIGEN2 Cross Section Libraries Based on JENDL4.0: ORILIBJ40 (JAEA, Ibaraki, 2013)

6. Japan Nuclear Fuel Limited (JNFL), Partial amendments in the application for designation and authorization of reprocessing business (2018) (in Japanese) 